\title{
BENTUK KECURANGAN AKADEMIK (ACADEMIC CHEATING) MAHASISWA PGMI FAKULTAS TARBIYAH DAN KEGURUAN UIN ALAUDDIN MAKASSAR
}

\author{
Nursalam, Suddin Bani, dan Munirah \\ Fakultar Tarbiyah dan Keguruan UIN Alauddin Makassar \\ Kampus II: Jalan Sultan Alauddin no 36 Samata-Gowa \\ Email: nursalam_ftk@uin-alauddin.ac.id
}

\begin{abstract}
Abstrak:
Penelitian ini bertujuan untuk mengetahui bentuk-bentuk kecurangan akademik (academic cheating) mahasiswa PGMI Fakultas Tarbiyah dan Keguruan UIN Alauddin Makassar. Hasil penelitian menunjukkan bahwa bentuk-bentuk kecurangan akademik yang dilakukan oleh mahasiswa PGMI adalah menyontek pekerjaan teman pada saat ujian, membuka buku saat ujian, menyalin tugas teman, membuka internet melalui handphone, copy paste dari internet. Faktor-faktor yang menyebabkan mahasiswa melakukan kecurangan akademik adalah sangat sulit mengerjakan tugas yang diberikan oleh dosen membutuhkan jawaban yang real, mahasiswa terpengaruh dengan adanya mahasiswa lain yang menyontek, soal yang diberikan oleh dosen terlalu sulit, waktu yang disediakan sangat singkat, mahasiswa tidak memahami materi yang diujikan, ragu dengan jawaban sendiri, tidak ada hukuman yang diberikan jika berbuat curang, mendapatkan nilai yang bagus.
\end{abstract}

\begin{abstract}
:
This study aims to determine the forms of academic cheatings of the students of Madrasah Ibtidaiyah Teacher Education Program at Tarbiyah and Teacher Training Faculty of UIN Alauddin Makassar. The results showed that the forms of academic cheating committed by the students while doing the exam are copying their friends' work, opening book, copying friend' task, open the internet via mobile phones, and doing copy-paste from the internet. The factors that lead to student academic cheating is the task given by the lecturers is very difficult and it needs text-book answers, the students affected by the presence of other students who cheat, questions given by the lecturers were too difficult, the time provided in the exam is very short, the students do not understand the material tested, they are unsure with their own answers, no penalty is given for cheating, and even the cheaters get good grades.
\end{abstract}

\section{Kata kunci: \\ Cheating, Academic cheating, Mahasiswa}

LEMBAGA pendidikan formal mulai dari tingkat dasar, menengah, sampai dengan perguruan tinggi diharapkan mampu menghasilkan lulusan yang berkualitas. Salah satu tolok ukur dari keberhasilan dari kualitas pendidikan adalah nilai evaluasi dari hasil pembelajaran. Setiap peserta didik, baik siswa pada jenjang pendidikan dasar dan menengah maupun mahasiswa pada level perguruan tinggi tentunya ingin mendapatkan nilai yang baik karena nilai tersebut menjadi salah satu hal yang menjadi tolok ukur kesuksesan seseorang. Sehingga segala upaya dilakukan agar dapat berhasil dalam ujian, termasuk dengan cheating (kecurangan). 
Cheating merupakan salah satu fenomena pendidikan yang sering muncul menyertai aktivitas proses pembelajaran dan dalam proses penilaian bahkan sampai pada penulisan tugas akhir. Cheating merupakan perbuatan yang menggunakan caracara yang tidak sah untuk mendapatkan keberhasilan akademis atau menghindari kegagalan akademis. Periaku curang pada dasarnya akan mengaburkan hasil kemampuan peserta didik. Perilaku curang dibagi dalam tiga kategori yaitu (1) memberi, mengambil, atau menerima informasi tertentu, (2) menggunakan suatu alat yang dilarang, (3) memanfaatkan kelemahan orang, prosedur, proses untuk mendapatkan keuntungan. ${ }^{1}$ Berdasarkan kedua definisi di atas, dapat disimpulkan bahwa kecurangan adalah suatu perbuatan yang dilakukan dengan cara-cara yang tidak baik untuk mendapatkan keuntungan. Seorang peserta didik yang dibiasakan untuk berbuat curang akan menjadi sebuah perilaku yang akan terus berulang karena nantinya peserta didik tersebut akan tumbuh menjadi orang-orang dewasa yang tidak jujur dan tidak bertanggung jawab. Hal itu akan memberikan efek yang buruk jika nantinya mereka menjadi orang-orang penting di dalam sebuah pemerintahan.

Perilaku cheating terjadi hampir di semua tingkat satuan pendidikan mulai dari sekolah dasar (SD) sampai Perguruan Tinggi (PT). Berdasarkan survei yang telah dilakukan Survei Litbang Media Group pada 19 April 2007 terhadap 480 responden dewasa di enam kota besar di Indonesia, yaitu Makassar, Surabaya, Yogyakarta, Bandung, Jakarta, dan Medan menunjukkan mayoritas anak didik, baik di bangku sekolah dan perguruan tinggi melakukan kecurangan akademik dalam bentuk menyontek. Hampir 70 persen responden yang ditanya apakah pernah menyontek ketika masih sekolah atau kuliah, menjawab pernah. Bahkan hasil penelusuran yang dilakukan oleh peneliti ditemukan adanya tugas akhir (skripsi ) mahasiswa yang mengindikasikan adanya praktik copy paste atau plagiarism dari satu skripsi dengan skripsi yang lainnya.

Cizek mengemukakan bahwa ada lima variabel yang diistilahkan sebagai "the big five" yang berkorelasi dengan kecurangan (cheating) yaitu jenis kelamin (gender), prestasi (achievement), usia (age), keanggotaan dalam kelompok/perkumpulan mahasiswa (membership in a fraternity or sorority), dan religiusitas (religiousity). ${ }^{2}$ Praktik kecurangan pada umumnya banyak dilakukan oleh peserta tes yang berjenis kelamin laki-laki dibandingkan perempuan. Hal ini menunjukkan bahwa perempuan lebih mematuhi peraturan dibandingkan laki-laki. Penelitian tentang motivasi berprestasi siswa yang berkorelasi dengan praktik kecurangan (cheating) di antaranya penelitian yang dilakukan oleh Roig dan Neaman dengan mengambil sampel sempel 154 mahasiswa di perguruan tinggi dan hasilnya menunjukkan bahwa tidak ada hubungan antara kecurangan yang dilakukan dengan motivasi berprestasi mahasiswa. ${ }^{3}$ Sedangkan Johnson dan Gormly menemukan bahwa siswa kelas lima sekolah dasar memiliki hubungan yang tinggi antara motivasi berprestasi dengan kecurangan khususnya bagi siswa laki-laki. ${ }^{4}$ Berdasarkan penelitian tersebut, maka praktik kecurangan yang dilakukan oleh siswa sekolah dasar dan mahasiswa memiliki motif yang berbeda. Siswa 
sekolah dasar melakukan kecurangan karena ingin lebih menunjukkan berprestasi yang lebih baik. Hal ini juga menunjukkan bahwa jika ditinjau dari segi usia, maka mahasiswa yang memiliki usia lebih muda, lebih banyak melakukan kecurangan dibanding mahasiswa yang lebih tua. Berkaitan dengan variabel keanggotaan dalam kelompok/perkumpulan mahasiswa, maka mahasiswa yang tergabung dalam suatu kelompok/perkumpulan lebih sering melakukan perilaku curang. ${ }^{5}$ Hal ini terjadi karena para mahasiswa dalam kelompok/perkumpulannya lebih mudah untuk mengakses dan mendapatkan catatan yang lama dan tugas-tugas akademik yang diberikan.

Penelitian yang dilakukan oleh Bushway dan Nash menunjukkan bahwa siswa tidak mengetahui hubungan antara kecurangan dan moralitas. ${ }^{6}$ Nonis dan Swift menunjukkan adanya korelasi yang kuat antara perilaku curang yang dilakukan oleh mahasiswa program studi bisnis dan manajemen pada semua strata dengan perilaku tidak etis yang mereka tampakkan di tempat kerja. ${ }^{7}$ Hal ini menunjukkan bahwa perilaku curang menjadi masalah moral. Akan tetapi perilaku curang tidak hanya menjadi masalah moral, tetapi juga berdampak secara psikologi yaitu dapat mempengaruhi kepercayaan diri pada diri seseorang. Seorang peserta didik yang terbiasa menyontek akan menilai hasil yang diperolehnya adalah karena kecurangannya, sehingga jika menginginkan kesuksesan peserta didik tersebut akan kembali memakai cara yang sama dan akhirnya tidak mengandalkan kemampuan dirinya lagi.

Kecurangan dalam pelaksanaan ujian terjadi karena beberapa faktor, baik dari siswa sebagai peserta tes maupun kecurangan yang merupakan akibat dari luar. Stern dan Havlicek melaporkan tentang tipe kecurangan yang dilakukan oleh siswa yaitu di antaranya menyalin jawaban dari siswa lain, menerima jawaban dari siswa lain secara cuma-cuma, meminta izin untuk melihat jawaban siswa lain ketika pelaksanaan kuis atau ujian, melakukan copying dari buku pada saatu ujian sementara sifat ujiannya adalah tutup buku. ${ }^{8}$

Steiner mengemukakan bentuk-bentuk kecurangan dan ketidakjujuran dalam pelaksanaan ujian adalah menyalin jawaban dari bagian belakang kartu, menyalin pekerjaan temannya, keliru menulis apa yang dilihat, didengar, atau dilakukan. ${ }^{9} \mathrm{Me}-$ nyontek adalah salah satu bentuk kecurangan akademik. Kecurangan akademik yang paling sering dilakukan oleh mahasiswa adalah pelanggaran terhadap peraturan-peraturan dalam menyelesaikan ujian atau tugas, memberikan keuntungan kepada mahasiswa lain di dalam ujian atau tugas dengan cara tidak jujur, dan pengurangan keakuratan yang diharapkan pada performansi mahasiswa.

Bushway dan Nash mengemukakan bahwa kecurangan di dalam kelas meliputi banyak perilaku di antaranya menggunakan buku catatan pada saat ujian, menyalin jawaban dari pekerjaan siswa yang lain, membiarkan orang lain menyalin pekerjaan rumah, menjiplak, dan lain-lain. ${ }^{10}$

Academic Cheating atau kecurangan akademik adalah perilaku tidak etis yang dilakukan dengan sengaja oleh mahasiswa meliputi pelanggaran terhadap aturan-atu- 
ran dalam menyelesaikan tugas atau ujian dengan cara yang tidak jujur, pengurangan keakuratan yang diharapkan dari performansi mahasiswa dengan penekana pada tindak mencontek, plagiarism, mencuri serta memalsukan sesuatu yang berhubungan dengan akademik.

Dalam konteks pendidikan atau sekolah, beberapa perbuatan yang termasuk dalam kategori cheating antara lain meniru pekerjaan teman, bertanya langsung pada teman ketika sedang mengerjakan tes/ujian, membawa catatan pada kertas, pada anggota badan atau pada pakaian masuk ke ruang ujian, menerima dropping jawaban dari pihak luar, mencari bocoran soal, arisan (saling tukar) mengerjakan tugas dengan teman, menyuruh atau meminta bantuan orang lain dalam menyelesaikan tugas ujian di kelas atau tugas penulisan paper, dan take home test.

Praktik cheating banyak macamnya, dimulai dari bentuk yang sederhana sampai kepada bentuk yang canggih. Teknik cheating tampaknya mengikuti pula perkembangan teknologi, artinya semakin canggih teknologi yang dilibatkan dalam pendidikan maka semakin canggih pula bentuk cheating yang bakal menyertainya. Bervariasi dan beragamnya bentuk perbuatan yang dapat dikategorikan sebagai cheating maka sekilas dapat diduga bahwa hampir semua pelajar pernah melakukan cheating meskipun mungkin wujudnya sangat sederhana dan dapat ditolerir.

Meskipun demikian dapat dikatakan bahwa apapun bentuknya, dengan cara sederhana ataupun dengan cara yang canggih, dari sesuatu yang sangat tercela sampai kepada yang mungkin dapat ditolerir, cheating tetap dianggap oleh masyarakat umum sebagai perbuatan ketidakjujuran, perbuatan curang yang bertentangan dengan norma agama serta tercela untuk dilakukan oleh seseorang yang terpelajar.

Terdapat beberapa faktor yang menyebabkan dan memengaruhi terjadinya tindak kecurangan akademik. Poltorak menyatakan bahwa alasan siswa melakukan kecurangan adalah adanya suatu perilaku menyimpang dalam hal kesalahan sistem pendidikan, struktur sosial, struktur ekonomi, dan politik. ${ }^{11}$ Mc Cabe, Trevino, dan Butterfield menunjukkan bahwa faktor dominan yang menyebabkan kecurangan adalah faktor kontekstual yaitu persepsi dari rekan-rekan siswa dan integritas institusi akademik terhadap perilaku siswa seperti kehormatan. ${ }^{12}$ Penelitian yang dilakukan oleh Jordan mengemukakan bahwa ada dua jenis motivasi yang menyebabkan orang melakukan kecurangan dan tidak melakukan kecurangan yaitu penguasaan dan motivasi ekstrinsik. ${ }^{13}$ Dengan demikian, dapat dikatakan bahwa praktik kecurangan terjadi karena faktor internal dan eksternal dari siswa sebagai peserta tes.

Penelitian yang dilakukan bertujuan untuk mengetahui bentuk-bentuk ketidakjujuran akademik (academic dishonesty), faktor yang menyebabkan mahasiswa melakukan ketidakjujuran akademik, hubungan antara jenis kelamin, latar belakang pendidikan, dan masa studi dengan kecurangan akademik mahasiswa Program Studi Pendidikan Guru Madrasah Ibtidaiyah (PGMI) Fakultas Tarbiyah dan Keguruan UIN Alauddin Makassar 


\section{METODE PENELITIAN}

Penelitian ini merupakan jenis penelitian kuantitatif dengan desain penelitian deskriptif eksploratif karena penelitian ini akan mendeskripsikan bentuk-bentuk kecurangan akadmeik yang dilakukan oleh mahasiswa Program Studi Pendidikan Guru Madrasah Ibtidaiyah (PGMI) Fakultas Tarbiyah dan Keguruan UIN Alauddin Makassar. Selain itu, penelitian ini juga untuk mengeksplorasi faktor-faktor penyebab kecurangan akademika. Populasi penelitian ini adalah seluruh mahasiswa Program Studi Pendidikan Guru Madrasah Ibtidaiyah (PGMI) Fakultas Tarbiyah dan Keguruan UIN Alauddin Makassar yang terdiri atas angkatan 2010 sebanyak 84 orang, angkatan 2011 sebanyak 108 orang, dan angkatan 2012 sebanyak 108 orang. Dengan demikian, jumlah populasi dari penelitian ini adalah 300 orang. Teknik sampling yang digunakan dalam penelitian ini adalah Proporsional Random Sampling. Jumlah sampel yang dibutuhkan dalam penelitian ini adalah 50 orang. Dengan demikian, secara proporsional tiap-tiap angkatan akan terwakili yaitu angkatan 2010 sebanyak 14 orang, angkatan 2011 sebanyak 18 orang, dan angkatan 2012 sebanyak 18 orang.

Pengumpulan data dilakukan dengan menggunakan kuisioner yang disusun peneliti berdasarkan teori tentang bentuk ketidakjujuran akademik. Kuisioner ini berisi beberapa pertanyaan terbuka. Analisis data adalah analisis deskriptif yang bertujuan untuk mendeskripsikan bentuk ketidakjujuran akademik mahasiswa PGMI Fakultas Tarbiyah dan Keguruan UIN Alauddin Makassar dan faktor penyebab kecurangan akademik yang dilakukan oleh mahasiswa.

\section{HASIL PENELEITIAN}

Penelitian tentang kecurangan akademik yang dilakukan pada program studi Pendidikan Guru Madrasah Ibtidaiyah (PGMI) dilakukan dengan melibatkan berbagai variabel yang berpengaruh. Di antara variable yang dimaksud adalah jenis kelamin, latar belakang pendidikan di SMA/MA/SMK, prestasi akademik, dan masa studi.

Penelitian tentang bentuk kecurangan akademik dilakukan pada program studi Pendidikan Guru Madrasah Ibtidaiyah (PGMI) yang melibatkan mahasiswa PGMI angkatan 2010, angakata 2011, dan angkatan 2012 yang tiap-tiap angkatan memasuki semester 3, semester 5, dan semester 7 . Adapun deskripsi tentang responden dapat dilihat pada gambar 1 dan gambar 2 .

Gambar 1 menunjukkan bahwa jumlah mahasiswa yang terpilih menjadi responden adalah 50 orang yang terdiri atas 7 orang mahasiswa angkatan 2010 dengan jenis kelamin laki-laki dan 7 orang mahasiswa dengan jenis kelamin perempuan. Angkatan 2011 terdiri atas 12 orang mahasiswa laki-laki dan 6 orang mahasiswa perempuan. Angkatan 2012 terdiri atas 7 orang mahasiswa laki-laki dan 11 orang mahasiswa perempuan. 


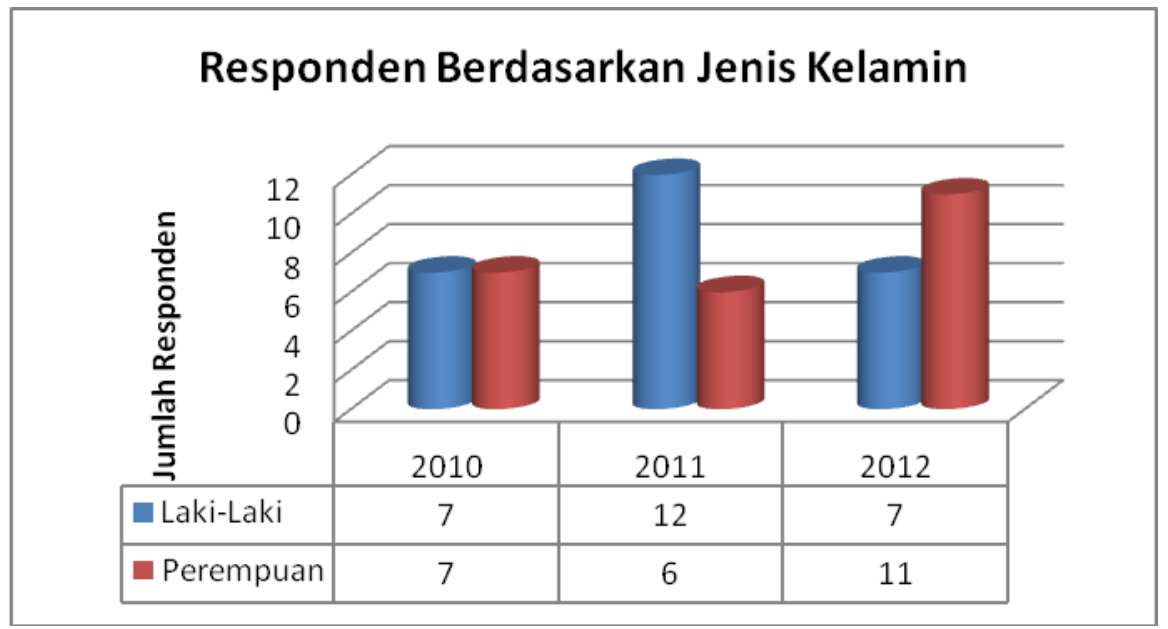

Gambar 1. Jumlah Responden Berdasarkan Jenis Kelamin

Gambar 2 menunjukkan bahwa jumlah mahasiswa yang menjadi responden yang didasarkan atas latar belakang pendidikan di SMA/MA/SMK adalah 16 orang mahasiswa yang berlatar belakang jurusan IPA, 22 orang mahasiswa dengan latar belakang pendidikan juruan IPS, dan 11 orang dengan latar belakang pendidikan jurusan Bahasa.

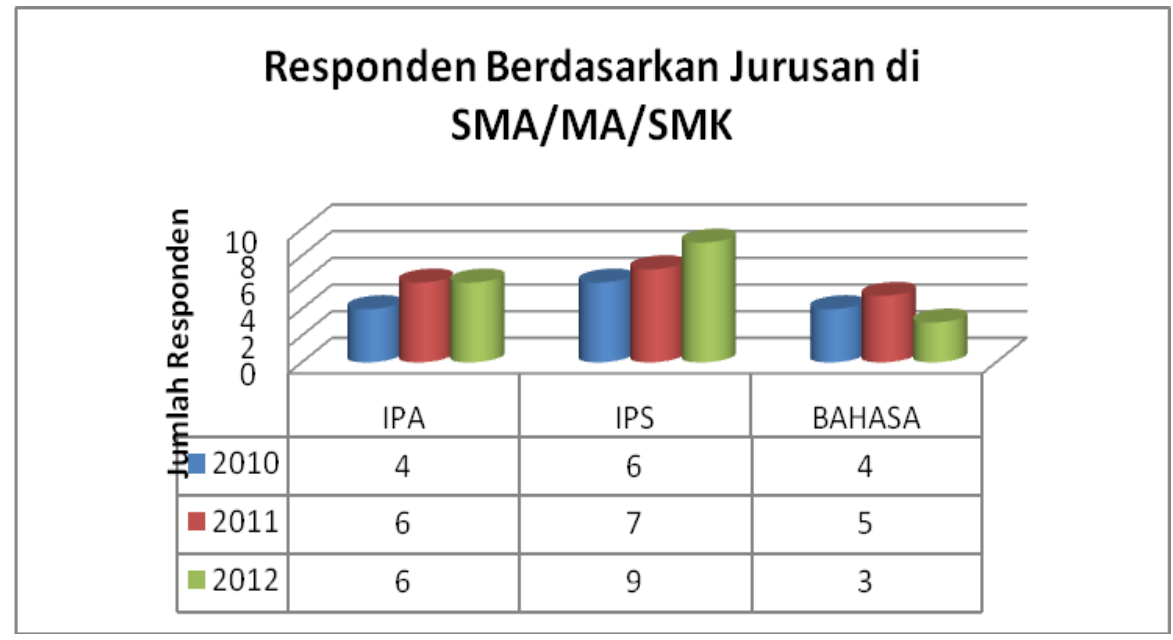

Gambar 2. Jumlah Responden Berdasarkan Jurusan di SMA/MA/SMK

Bentuk-bentuk Kecurangan Akademik Mahasiswa Program Studi Pendidikan Guru Madrasah Ibtidaiyah (PGMI) Fakultas Tarbiyah dan Keguruan UIN Alauddin Makassar

Hasil penelitian tentang bentuk kecurangan akademik yang dilakukan oleh mahasiswa program studi Pendidikan Guru Madrasah Ibtidaiyah (PGMI) Fakultas Tarbiyah dan Keguruan UIN Alauddin Makassar adalah menyontek pekerjaan teman, copy paste dari internet, menyalin tugas teman, membuka buku saat ujian, dan membuka internet melalui handphone. Berikut akan dijelaskan tentang bentuk kecurangan yang dilakukan oleh mahasiswa. 


\section{Menyontek}

Menyontek merupakan salah satu bentuk kecurangan akademik yang dilakukan oleh mahasiswa selama pelaksanaan perkuliahan. Menyontek terjadi ketika pelaksanaan ujian. Hasil penelitian ini menunjukkan bahwa sekitar 88\% mahasiswa melakukan kegiatan mencontek selama pelaksanaan ujian dan sisanya sekirat $12 \%$ tidak pernah melakukan kegiatan mencontek selama pelaksanaan ujian. Diagram berikut menunjukkan tentang respons mahasiswa tentang perilaku menyontek saat ujian.

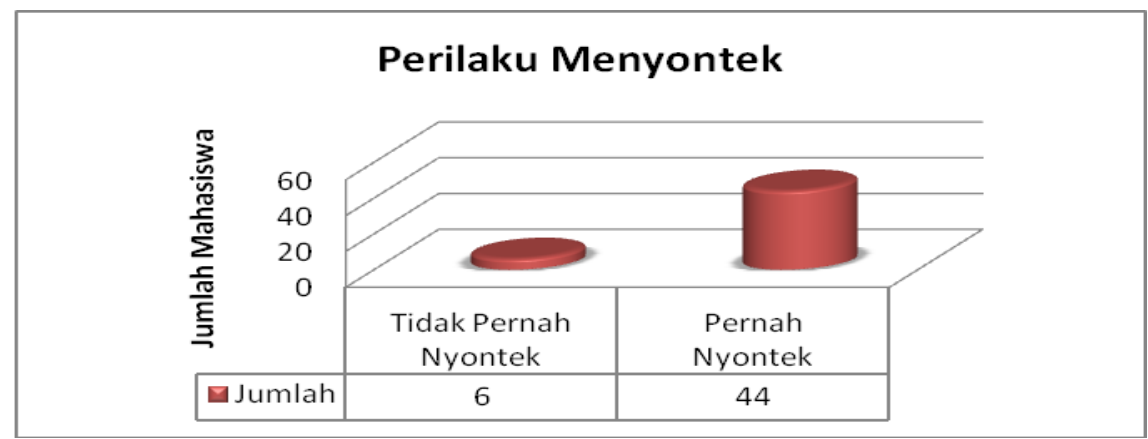

Gambar 3. Frekuensi Distribusi Perilaku Menyontek Mahasiswa

Berdasarkan gambar 3, tampak bahwa dari 50 mahasiswa yang menjadi responden terdapat 44 orang mahasiswa yang menyatakan pernah menyontek saat ujian dan 6 orang sisanya menyatakan tidak pernah menyontek selama menjadi mahasiswa. Berkaitan dengan kegiatan menyontek ini disajikan frekuensi kegiatan menyontek mahasiswa dalam pelaksanaan ujian sebagaimana yang disajikan pada gambar 4 .

Gambar 4 menunjukkan bahwa kegiatan menyontek yang dilakukan oleh mahasiswa pada dasarnya dilakukan dengan frekuensi yang cukup tinggi. Hal ini bisa dilihat pada data bahwa 28 mahasiswa yang melakukan kegiatan menyontek kurang dari 2 kali, 13 mahasiswa yang menyontek antara 2 sampai 4 kali, terdapat 5 mahasiswa yang menyontek sebanyak 5 sampai 8 kali, dan sisanya 4 orang mahasiswa yang menyontek lebih dari 8 kali. Hasil ini menunjukkan bahwa frekuensi aktivitas menyontek mahasiswa dalam pelaksanaan ujian ternyata sangat tinggi. Dengan demikian, perlu pengawasan yang ketat pada pelaksana ujian atau dosen ketika pelaksanaan ujian berlangsung.

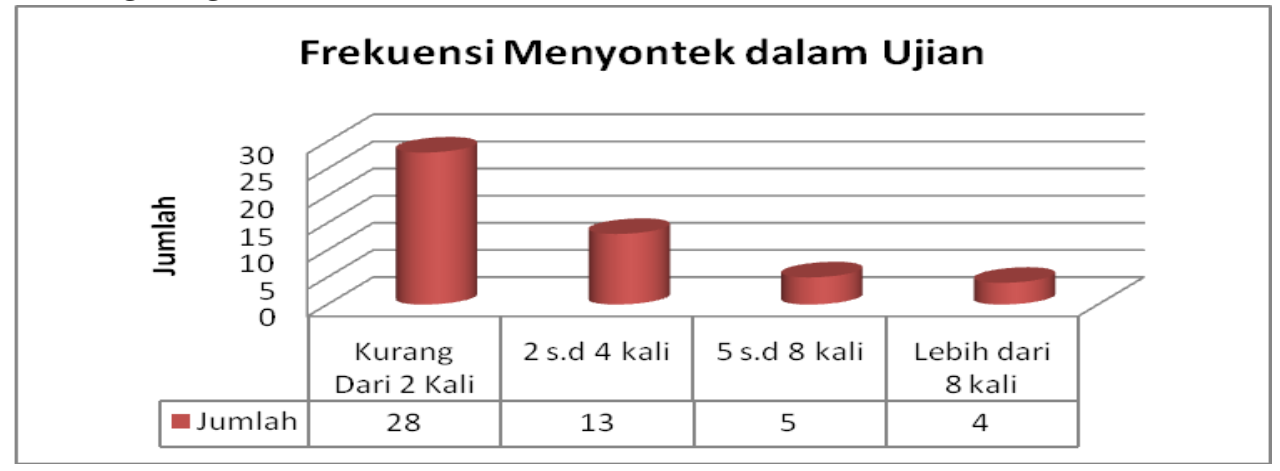

Gambar 4. Frekuensi Menyontek dalam Ujian 
Berkaitan dengan kegitan menyontek ketika pelaksanaan ujian, tanggapan responden terkait dengan seringnya mahasiswa kedapatan oleh dosen ketika menyontek, berdasarkan data yang ada maka terdapat 25 mahasiswa yang menyatakan sangat sering kedapatan menyontek oleh dosen, 21 orang mahasiswa menyatakan sering, 4 orang mahasiswa yang kadang-kadang kedapatan oleh dosen menyontek, dan tidak ada seorang pun mahasiswa yang menytakan tidak pernah kedapatan menyontek oleh dosen ketika pelaksanaan ujian. Terkait dengan hal ini, maka dapat dilihat pada gambar 5 berikut.

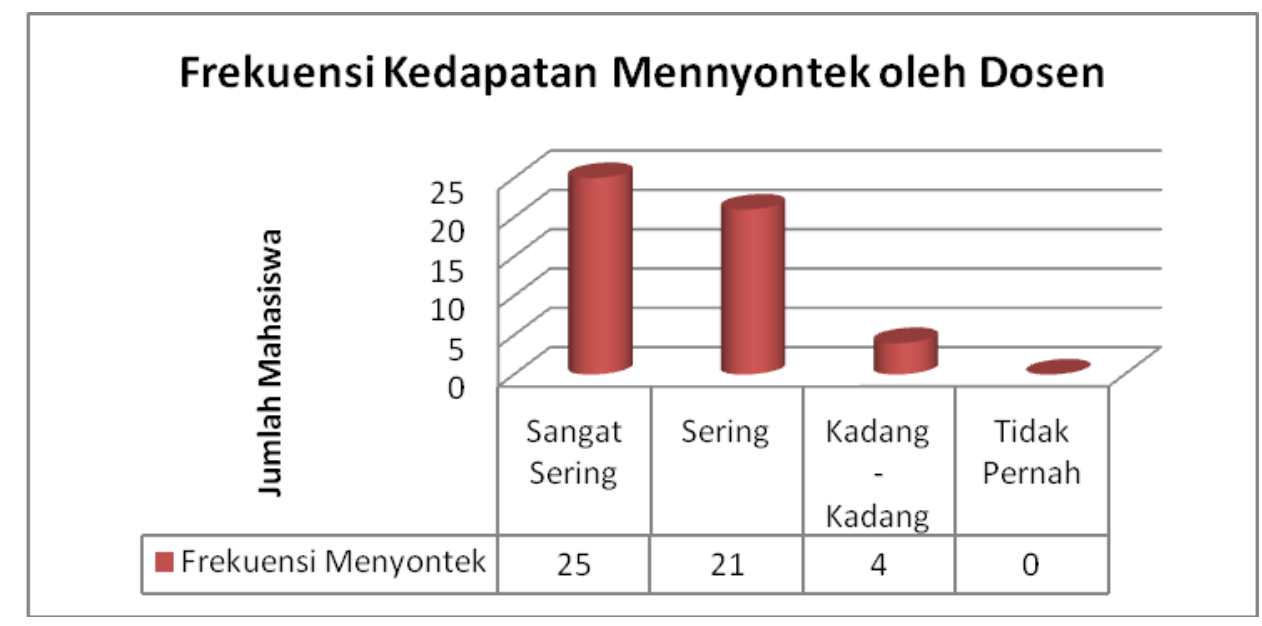

Gambar 5. Frekuensi Distribusi Mahasiswa Yang Kedapatan Menyontek

\section{Copy paste dari internet}

Copy paste materi dari internet merupakan salah satu bentuk kecurangan akademik yang dilakukan oleh mahasiswa khususnya ketika para mahasiswa diminta untuk membuat makalah dan tugas-tugas yang diberikan oleh dosen untuk diselesaikan di luar kegiatan perkuliahan.

\section{Menyalin tugas teman}

Bentuk kecurangan akademik yang ketiga adalah menyalin tugas teman. Mahasiswa menyain tugas dari teman khususnya yang bersifat tugas tertulis. Misalnya penyelesaian soal-soal yang bersifat eksak (matematika dan IPA).

\section{Membuka buku saat ujian}

Membuka buku pada saat ujian merupakan salah satu bentuk kecurangan akademik yang dilakukan oleh mahasiswa pada saat pelaksanaan ujian. Para mahasiswa berusaha membuka buku ketika soal-soal yang diberikan oleh dosen merupakan soalsoal yang termasuk kategori sulit sehingga mereka tidak mampu mengerjakannya dan mahasiswa tidak memiliki akses untuk melihat pekerjaan teman yang ada di dekatnya. 


\section{Membuka internet melalui handphone}

Berdasarkan data yang terkumpul, hasil respon mahasiswa menyatakan bahwa ketika pelaksanaan ujian berlangsung dan ujian dalam bentuk tes uraian, mahasiswa memilih untuk mencari jawaban pertanyaan yang ada melalui handphone yang terkoneksi langsung dengan internet.

\section{Faktor-Faktor Penyebab Kecurangan Akademik Mahasiswa Program Studi Pendidikan Guru Madrasah Ibtidaiyah (PGMI) Fakultas Tarbiyah dan Keguruan UIN Alauddin Makassar}

Hasil penelitian yang dilakukan kepada mahasiswa program studi Pendidikan Guru Madrasah Ibtidaiyah (PGMI) Fakultas Tarbiyah dan Keguruan UIN Alauddin Makassar ditemukan bahwa ada beberapa faktor penyebab para mahasiswa tersebut melakukan kecurangan akademik. Faktor peyebab dari kecurangan tersebut adalah sebagai berikut:

a. Sangat sulit mengerjakan tugas yang diberikan oleh dosen

b. Membutuhkan jawaban yang real

c. Mahasiswa terpengaruh dengan adanya mahasiswa lain yang menyontek

d. Soal yang diberikan oleh dosen terlalu sulit

e. Waktu yang disediakan sangat singkat

f. Mahasiswa tidak memahami materi yang diujikan

g. Ragu dengan jawaban sendiri

h. Tidak ada hukuman yang diberikan jika berbuat curang

i. Mendapatkan nilai yang bagus

Dari berbagai alasan yang dikemukakan di atas, dapat disimpulkan bahwa faktor penyebab kecurangan akademik dibagi atas dua bagian yaitu: kecurangan yang terjadi saat pelaksanaan ujian dan kecurangan yang terjadi akibat tugas yang diberikan oleh dosen.

Faktor penyebab kecurangan pada saat ujian adalah soal yang diberikan dosen memerlukan jawbaan yang real, mahasiswa terpengaruh oleh kecurangan yang dilakukan oleh mahasiswa yang lain, soal yang diberikan oleh dosen sangat sulit, waktu mengerjakan soal sangat sedikit, tidak ada hukuman yang diberikan ketika mahasiswa berbuat curang, dan mendapatkan nilai yang bagus. Faktor penyebab kecurangan mahasiswa ketika menyelesaikan tugas adalah agar tugas yang diberikan cepat selesai, mahasiswa tidak memahai materi yang diberikan, dan ragu dengan jawaban sendiri.

Penelitian tentang bentuk-bentuk kecurangan akademik (academic cheating) yang dilakukan pada program studi Pendidikan Guru Madrasah Ibtifaiyah (PGMI) Fakutas Tarbiyah dan Keguruan UIN Alauddin Makassar menujukkan bahwa ada beberapa bentuk kecurangan akademik yang dilakukan mahasiswa selama terdaftar sebagai mahasiswa yaitu menyontek pekerjaan teman pada saat ujian, copy paste dari internet, menyalin tugas teman, membuka buku saat ujian, dan membuka internet melalui handphone. 
Mahasiswa yang melakukan kecurangan akademik dilakukan dengan berbagai alasan. Berdasarkan hasil penelitian, alasan mahasiswa melakukan kecurangan adalah sangat sulit mengerjakan tugas yang diberikan oleh dosen, membutuhkan jawaban yang real, mahasiswa terpengaruh dengan adanya mahasiswa lain yang menyontek, soal yang diberikan oleh dosen terlalu sulit, waktu yang disediakan sangat singkat, mahasiswa tidak memahami materi yang diujikan, ragu dengan jawaban sendiri, tidak ada hukuman yang diberikan jika berbuat curang, dan mendapatkan nilai yang bagus.

Berdasarkan alasan mahasiswa, maka ada beberapa hal yang perlu mendapat perhatian khusus dari pelaksana tes dan dosen. Khusus untuk pelaksana tes dalam ha ini panitia ujian diharapkan untuk mengatur posisi tempat duduk sedemikian rupa sehingga tidak memberikan peluang kepada mahasiswa untuk mengakses pekerjaan mahasiswa yang lain. Selain itu, panitia ujian dalam hal ini pengawas ruangan untuk melakukan pengawasan yang ketat ketika ujian berlangsung termasuk di dalamnya tidak memberikan kesempatan kepada peserta tes (mahasiswa) untuk mengaktifkan HP ketika ujian berlangsung.

Penyebab yang paling berpengaruh terhadap kecurangan yang dilakukan mahasiswa adalah tidak adanya hukuman yang diberikan kepada mahasiswa yang melakukan kecurangan. Oleh karena itu, diharapkan agar dosen ketika memberikan ujian kepada mahasiswa dan teridentifikasi ada mahasiswa yang melakukan kecurangan untuk memberikan tindakan yang tegas kepada mahasiswa yang bersangkutan.

Hasil penelitian menunjukkan bahwa tidak ada hubungan antara jenis kelamin, latar belakang pendidikan SMA/MA/SMK, dan masa studi dengan kecurangan akademik mahasiswa program studi Pendidikan Guru Madrasah Ibtidaiyah (PGMI) Fakultas Tarbiyah dan Keguruan UIN Alauddin Makassar yang ditunjukkan oleh uji statistik chi-square. Hal ini menunjukkan bahwa mahasiswa yang berjenis kelamin laki-laki ataupun perempuan sama-sama melakukan kecurangan akademik. Demikian pula mahasiswa yang berlatar pendidikan jurusan IPA, IPS, ataupun Bahasa, juga sama-sama melakukan kecurangan akademik.

\section{SIMPULAN}

Bentuk kecurangan akademik yang dilakukan mahasiswa program studi Pendidikan Guru Madrasah Ibtidaiyah (PGMI) Fakutas Tarbiyah dan Keguruan UIN Alauddin Makassar yaitu menyontek pekerjaan teman pada saat ujian, copy paste dari internet, menyalin tugas teman, membuka buku saat ujian, dan membuka internet melalui handphone.

Faktor-faktor yang mempengaruhi mahasiswa melakukan kecurangan akademik adalah sangat sulit mengerjakan tugas yang diberikan oleh dosen membutuhkan jawaban yang real, mahasiswa terpengaruh dengan adanya mahasiswa lain yang menyontek, soal yang diberikan oleh dosen terlalu sulit, waktu yang disediakan sangat singkat, mahasiswa tidak memahami materi yang diujikan, ragu dengan jawaban sendiri, tidak ada hukuman yang diberikan jika berbuat curang, dan mendapatkan nilai yang bagus. 
Hasil penelitian ini menunjukkan bahwa tidak ada hubungan antara jenis kelamin, latar belakang pendidikan di SMA/MA/SMK, dan masa studi dengan kecurangan akademik mahasiswa program studi Pendidikan Guru Madrasah Ibtifaiyah (PGMI) Fakutas Tarbiyah dan Keguruan UIN Alauddin Makassar

\section{IMPLIKASI PENELITIAN}

Kepada pelaksana ujian agar sebelum ujian berlangsung untuk mengatur tempat ujian agar tidak memungkinkan mahasiswa memiliki akses untuk melihat pekerjaan mahasiswa lain. Dosen diharapkan memberikan hukuman yang keras kepada mahasiswa yang teridentifikasi melakukan kecurangan. Kepada pimpinan Perguruan Tinggi, dalam hal ini penentu kebijakan untuk mengambil tindakan tegas sesuai aturan akademik yang beraku terhadap mahasiswa yang teridentifikasi melakukan tindak kecurangan akademik (academic cheating).

\section{CATATAN AKHIR}

1. Cizek, Detecting and preventing classroon cheating: promoting integrity in assessment, Thousand Oaks, CA: Corwin Press, 2003, h. 42.

2. G.J. Cizek, Cheating on tests: how to do it, detect it, and prevent it, Englewood Cliffs, NJ: Lawrence Erlbaum, 1999, h. 91.

3. M. Roig \& M.A.W. Neaman, "Alienation, learning or grade orientation, and achievement as correlates of attitudes toward cheating", Perceptual and motor skills, 78, 1994, h. 10961098.

4. C.D. Johnson \& J. Gormly, "Academic cheating: The contribution of sex, personality, and situational variables", Developmental Psychology, 6, 1972, h. 320.

5. B. Hendricks, "Academic dishonesty: a study in the magnitude of and justification for academic dishonesty among college undergraduade and graduade students". Journal of College Student Development, 35, 2004, h. 212 - 214.

6. A. Bushway \& W.R. Nash, "School Cheating Behavior", Review of Educational Research, 47, 1997. h. 628.

7. S. Nonis \& C.O. Swift, "An examination of the relationship between academic dishonesty and workplace dishonesty: A multicampus investigation". Journal of Education for Business, 77, 2001, h. 70-71.

8. E.B. Stern \& L. Havlicek, "Academic misconduct: results of faculty and undergraduate student surveys". Journal of Allied Health, 15, 1986. h. 133.

9. M.A. Steiner, "Cheating in School", The School Review, 40, 1932. h. 536 - 537.

10. A. Bushway \& W.R. Nash, "School Cheating Behavior". Review of Educational Research, 47, 1932. h. 623.

12. Y. Poltorak, "Cheating Behavior among Students of Four Moscow Institutes". Higher Education, 30, 1995. h. $225-227$.

13. D.L. Mc Cabe, L.K. Trevino \& K.D. Butterfield, "Cheating in Academic Institutions: A Decade of Research". Ethnics \& Behavior, 11, 2001. h. 220-221.

14. A.E. Jordan, "College student cheating: the role of motivation, perceived norms, attitudes, and knowledge of institutional policy", Ethics \& Behavior, 11, 2001. h. 234. 


\section{DAFTAR PUSATAKA}

Bower, W. J. Student Dishonesty and Its Control in College. New York: Columbia University, 1964.

Bushway, A. \& Nash, W. R. School Cheating Behavior. Review of Educational Research. 1997.

Cizek, G. J. Cheating on tests: how to do it, detect it, and prevent it. Englewood Cliffs, NJ: Lawrence Erlbaum, 1999.

Cizek, G. J. Detecting and Preventing Classroon Cheating: Promoting Integrity in Assessment. Thousand Oaks, CA: Corwin Press, 2003

Hendricks, B. "Academic Dishonesty: A Study in the Magnitude of and Justification for Academic Dishonesty Among College Undergraduade and Graduade Students". Journal of College Student Development, 2004.

Johnson, C. D. \& J. Gormly. "Academic Cheating: The Contribution of Sex, Personality, and Situational Variables". Developmental Psychology, 1972.

Jordan, A. E. College Student Cheating: The Role of Motivation, Perceived Norms, Attitudes, and Knowledge of Institutional Policy. Ethics \& Behavior, 2001.

McCabe, D. L., Trevino, L. K. \& Butterfield, K. D. “Cheating in Academic Institutions: A Decade of Research." Ethnics \& Behavior, 2001.

Nonis, S. \& C. Swift. "An Examination of the Relationship Between Academic Dishonesty and Workplace Dishonesty: A Multicampus Investigation." Journal of Education for Business, 2001.

Poltorak, Y. Cheating Behavior among Students of Four Moscow Institutes. Higher Education, 1995.

Roig, M., \& Neaman, M. A. W. Alienation. "Learning or Grade Orientation, and Achievement as Correlates of Attitudes Toward Cheating". Perceptual and Motor Skills, 1994.

Steiner, M. A. "Cheating in School". The School Review, 1932.

Stern, E. B., \& L. Havlicek. "Academic Misconduct: Results of Faculty and Undergraduate Student Surveys". Journal of Allied Health. 1986. 